\title{
Juvenile Justice and Punishment of Girls in Brazil: Knowledge Production and Research Perspectives
}

OÑATI SOCIO-LEGAL SERIES, VOLUME 10, ISSUE 2 (2020), 257-290: El GÉNERO DE LOS SISTEMAS PENALES JUVENILES: DEBATES NECESARIOS DOI LINK: HTTPS://DOI.ORG/10.35295/OSLS.IISL/0000-0000-0000-1056

RECEIVED 01 FEBRUARY 2019, ACCEPTED 21 MAY 2019

\author{
JALUSA Silva DE ARRUDA* (iD) \\ NATASHA MARIA WANGEN KRAHN* (D)
}

\section{Abstract}

This article presents a bibliographical review of research carried out within the scope of the Brazilian postgraduate programs that studied the execution of socioeducational measures on girls in the juvenile justice system and that adopted gender studies or feminist approaches as their theoretical perspective. Theses and dissertations that have been produced on the theme were identified and eventual gaps in these works were indicated, thus contributing to new possibilities of research on the subject in the country. We concluded that the studies developed in the scope of the postgraduate programs in addition to other studies on the subject give an overview of the situation of girls in the Brazilian socio-educational system, but that it is still necessary to further analyze modes of punishment that are especially applied to girls and interpret them considering the specificities of the Brazilian social reality, especially regarding the intersection between the social categories gender, race, class and generation.

\section{Key words}

Juvenile justice system; Brazilian socio-educational system; gender and feminism; knowledge production

\section{Resumen}

Este artículo presenta una revisión bibliográfica de las investigaciones realizadas en el ámbito de los programas de posgrado brasileños que abordaron la ejecución de

\footnotetext{
* Lawyer and assistant professor at the State University of Bahia (campus XV). Doctorate candidate in Social Sciences at the Federal University of Bahia and researcher at the Laboratory of Studies on Crime and Society (LASSOS/UFBA). Contact details: Av. Boulevar, 240, Bairro Novo Horizonte; Valença, Bahia, Brazil, postal code 45400-000. Email address: jsarruda@uneb.br

* Sociologist and doctorate candidate in Social Sciences at the Federal University of Bahia and researcher at the Laboratory of Studies on Crime and Society (LASSOS/UFBA). Contact details: Estrada de São Lázaro, 197, Federação, postal code 40.210-730, Salvador, Bahia, Brazil. Email address: natashak@ufba.br
} 
medidas socioeducativas por parte de mujeres adolescentes en el sistema de justicia juvenil y que adoptaron los estudios de género o los enfoques feministas como su perspectiva teórica. Se identificaron las disertaciones y las tesis que se produjeron sobre el tema y se señalaron las posibles lagunas en estos trabajos, lo que aporta nuevas posibilidades de investigación sobre el tema en el país. Concluimos que las investigaciones desarrolladas en el ámbito de los programas de posgrado, además de otros estudios sobre el tema, dan una visión general de la situación de las mujeres adolescentes en el sistema socioeducativo brasileño, pero aún es necesario analizar más a fondo los modos de castigo que son Especialmente aplicado a las mujeres adolescentes e interpretarlas teniendo en cuenta las especificidades de la realidad social brasileña, especialmente en relación a la intersección entre las categorías sociales género, raza, clase y generación.

\section{Palabras clave}

Sistema de justicia juvenil; sistema socioeducativo brasileño; género y feminismo; producción de conocimiento 


\section{Table of contents}

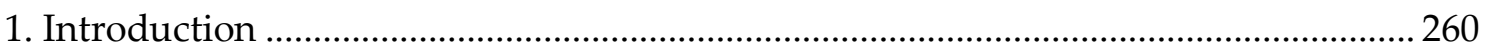

2. Brief overview of the Brazilian socio-educational system............................................ 263

3. Methodology and general aspects of the selected papers ……….................................. 264

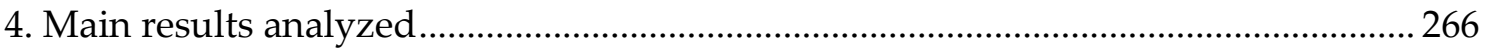

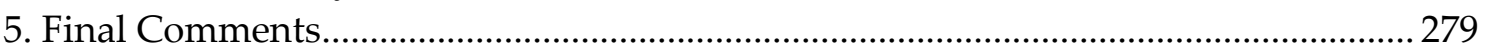

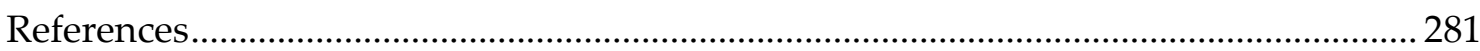

Dissertations (Master's) and theses (Doctorate) consulted...................................... 287

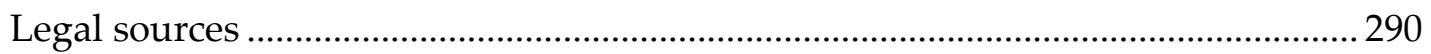




\section{Introduction}

Once the undifferentiated criminal character with which "minors" 1 were treated was removed, a new era in the treatment of criminal responsibility in Brazil was established at the beginning of the $20^{\text {th }}$ century, firstly with the institution of Decree $n^{\circ} 16,272$, dated 20 December 1923 and later with the institution of the Mello Mattos Code (Decree $\mathrm{n}^{\mathrm{o}}$ 17,943-A, of 12 October 1927) (Méndez 2006, Andrade and Machado 2017).

Decree $\mathrm{n}^{\mathrm{o}} 16,272 / 1923$ approved a specific regulation for the assistance and protection of abandoned and delinquent juveniles and dealt widely with their criminal responsibility, thus, without a doubt, this decree could be considered the first juvenile criminal law of Brazil. The decree established the first Court of Minors in Rio de Janeiro - capital of the Republic of the United States of Brazil at the time - in line with other Western countries that in the same period invested in the specialization of Justice of Minors, such as France and Belgium (1912), Spain (1918), Argentina (1919), Germany (1922), among others (Andrade and Machado 2017).

Shortly thereafter, the Mello Mattos Code was established. The Melo Mattos Code originated from an ensemble of existing laws and decrees from the beginning of the twentieth century that in any way dealt with persons under 18 years of age, among these the Decree $n^{0} 16,272 / 1923$. Therefore, this was the first legislation to deal specifically with all the rights inherent to children and adolescents (at that moment minors) in our country, reinforcing the educational sphere of the actions applicable to offenders and abandoned (Alvarez 1989, Saraiva 2003, Pereira 2008, J.S. Arruda 2011, Sposato 2013). Concerned with "making them politically and economically productive, moralized citizens and workers" (Alvarez 1989, p. 56), the specialization of the Right of the Minor was marked by the creation of specific courts and legislations that made the "minor issue" a strictly legal object. Years later the Code of Minors (Law no 6,697, dated 10 October 1979) was instituted - still during the military dictatorship in Brazil - to establish the "minor" as an object of State protection and to legitimize state intervention over those defined as in "irregular situation", binomial that implicitly condensed socio-economical vulnerability and delinquency and authorized indiscriminate confinement (Saraiva 2003, Sposato 2013).

The advent of the doctrine of integral protection inaugurated by the International Convention for the Rights of the Child, ${ }^{2}$ the promulgation of the Constitution of the Federative Republic of Brazil of 1988 and the Statute of the Child and Adolescent (Law no 8,069, of 13 July 1990 - hereinafter ECA) was committed to the rupture of the tutelary paradigms typical of the previous legislation and consolidated a new model of adolescent criminal responsibility with the objective of guaranteeing previously unrecognized rights, among which are the principle of contradictory and ample defense, the limitation of the magistrate's powers over the fate of children and adolescents, and

\footnotetext{
1 The expression "minor" is related to the models prior to the establishment of the doctrine of integral protection. From a legal point of view, it marked the tutelary period and was used to refer to poor, underprivileged and offending children and adolescents. In the current model the term was abandoned given the stigmatizing character it acquired. We use it at this point in the text in reference to the historical period, but from now on, in accordance with current policy, we will use the terms children and adolescents. 2 Approved by the General Assembly of the United Nations (UN) on 20 November 1989 and promulgated by the Brazilian State through Decree no 99,710, of 21 November 1990.
} 
the establishment of socio-educational measures in response to the practice of crime. The revocation of the doctrine of the irregular situation by the doctrine of integral protection replaced the Right of the Minor for the Right of the Child and the Adolescent and reaffirmed the citizenship dimension contained in childhood and youth. ${ }^{3}$

From the second half of the twentieth century, even before the advent of the doctrine of integral protection, interest in juvenile offenses and punishment began to emerge from distinct areas of the juridical field, with approaches that have explored the subject in different ways and contributed significantly to a more complete understanding of juvenile justice (Alvarez et al. 2017). From the modifications in the policy of assistance to the adolescent author of a crime, instituted by ECA, the interests and contributions of other areas became more and more significant since the socio-educational system works as a network and is articulated with the systems of justice and public security, health, education and social assistance at the municipal, state and federal levels. ${ }^{4}$ The decentralization of the political system has brought a range of knowledge to the socioeducational system that has had an impact on the development of studies and research on the subject.

Currently, research on the Brazilian socio-educational system contains a diversity of investigative approaches: there are several areas, distinct methods, several theoreticalmethodological approaches that consolidate it as a field and, therefore, not absent of epistemological and political disputes - elements that are inseparable from a Bourdieusian (1989) point of view. And, in the socio-educational field of study, there is a consensus in the specialized literature that adolescent girls and young women, from now on "girls", are secondary in studies and in research (Heidensohn 1996, Matos 2008, Duarte 2012, Chesney-Lind and Pasko 2013, Conselho Nacional de Justiça - CNJ - 2015, J.S. Arruda 2019).

It was from the 2000s that the juvenile justice system and the socio-educational system became consolidated as a field of research in Brazil (Bretan 2008) and girls gradually began to appear in the research of postgraduate programs. For example, a research dedicated to identify the production of knowledge about adolescents and crime in postgraduate programs at the University of São Paulo and at the Pontifical Catholic University of São Paulo between 1990 and 2006 presented significant data. However, of the 100 works that were found, only one had been dedicated exclusively to girls (Bretan 2008).

\footnotetext{
3 The appropriate technical terminology adopted with the advent of the doctrine of integral protection to refer to crimes committed by children and adolescents is an ato infracional [infractional act] (see article 103, ECA). The adoption of a different terminology from the one adopted in the adult penal system seeks to mark the distinction between the two systems - penal, for adults; and socio-educational, for adolescents. There is no distinction between the actual conduct, because what is considered a crime for adults is considered an infraction for adolescents, and it is also in the Brazilian Penal Code (Decree-Law no 2,848, 7 December 1940) that one seeks to find the typification of the act considered a crime. However, even referring to adolescents, in the course of the text we will use the word "crime" instead of the expression "infractional act" for better adaptation of the translation.

${ }^{4}$ The Socio-educational System is a public policy that organizes and guides programs for the implementation of socio-educational measures applied to adolescents who are attributed with the commission of a crime or criminal contravention. In the normative scope it was instituted by Law no 12,594, of 18 January 2012, known as the National System of Socio-Educational Assistance (SINASE).
} 
The work of Simone Assis and Patricia Constantino (2001) is referred to as the pioneer study on girls in the majority of works that approach the subject. The research that resulted in the Filhas do mundo: infração juvenil feminina no Rio de Janeiro [Daughters of the world: girls and crime in Rio de Janeiro] aimed at understanding what led girls to commit crime and what factors made it easier or more difficult to enter a criminal life. The study took place during 1998 and 1999 with girls carrying out socio-educational measures of incarceration and provisional incarceration ${ }^{5}$ and concluded that primary socialization institutions (mainly family and school) had a fragile influence on girls' lives. The increasing entry into the illegal drug market was related to the possibility of work and of having access to consumer goods. The profile of the girls was similar to that of adult women prisoners, especially regarding "previous history of violence, abandonment, drug use, family disorganization and the cooptation of women by criminal men" (Assis and Constantino 2001, p. 262), and the institution that implemented the measure did not promote equity in the socio-educational service considering the disparity in the quality of care given to boys and to girls. Also referred to as pioneer is the study that investigated the life trajectory of 50 girls who carried out socio-educational measures in the city of Porto Alegre, capital of Rio Grande do Sul, in the early 2000s. In order to investigate the factors that culminated in the practice of crime or criminal contraventions, "abandonment stories, rejection, discontinuation of family ties, maltreatment and exposure to violence" were pointed out as the main constituents of the risk factors to which girls were exposed (Dell'Aglio et al. 2004, p. 195). The authors understood that the girls' contextual risk factors were related to family, community, school and peer group contexts which influenced their development; that is to say, as in the Filhas do mundo [Daughters of the world], the fragility of the primary socialization institutions impacts lives in a way that could culminate in crime.

A possible synthesis of the pioneer studies lie on two issues that would be revisited in subsequent work: the distinct ways in which risk factors operate in the lives of girls as opposed to boys; and how the measure is executed that, relying on the girls experience, relegated them to the background and to worse quality of service in the socioeducational system. As in the studies dedicated to women in the penal and prison system, scholars studying about girls began to realize that it was necessary to produce reflections that effectively considered them as subjects, since the actor, the relevant

\footnotetext{
5 Socio-educational measures are actions that constitute legal responses to individual behaviors committed by adolescents (persons between 12 and 18 years of age) that are considered an infraction (crime or criminal contravention), applied by the competent authority. There are six types of socio-educational measures, from the mildest to the most serious: "warning", consisting of a verbal admonition, reduced to a term and signed (article 115, ECA); "obligation to repair the damage", in the case of a crime with patrimonial repercussions, the competent authority may determine, as the case may be, that the adolescent restore the thing, promote compensation for the damage, or, otherwise, to the victim (article 116, ECA); "provide services to the community", which consists of performing free-of-charge tasks of general interest with entities of care, hospitals, schools and other similar establishments, as well as in community or governmental programs (article 117, ECA); "assisted liberty", a measure adopted whenever the most appropriate measure is considered to accompany, assist and guide the adolescent (article 118, ECA); "semi-liberty regime", a liberty restrictive measure, the semi-liberty regime can be determined from the beginning, or as a means of transition to the open regime (article 120, ECA); "incarceration in a socio-educational institution", which is a deprivation of liberty measure, and may be applied for a maximum of three years (article 121, ECA). Provisional incarceration has a precautionary nature and must be applied for a maximum of 45 days when sufficient evidence of the offense or penal contravention has been demonstrated (articles 108 and 183 ECA).
} 
subject in the analysis of delinquency and crime tendentially were men, adults or not. Work on juvenile and socio-educational justice system was beginning to realize that "gender blindness" in the analyses (Smart 1980) ignored the fact that the social category of gender - and we imperiously include race - are profoundly significant dimensions of differentiation to reflect on crime and punishment (Duarte and Carvalho 2013).

From this point of view, the purpose of this article is to present a bibliographical review of research carried out within the scope of Brazilian postgraduate programs that have addressed, in any way, the implementation of socio-educational measures for girls. Intentionally, studies were selected whose authors indicated adherence to gender studies or who had in some way adopted the concept of gender to justify the focus of the work on the girls, as well as indicated adherence to the feminist theoretical perspectives for the analyzes they developed. The aim is to identify what has been produced so far, presenting in general terms the main results of the dissertations and theses, indicate possible gaps and contribute with new possibilities of research and analysis on the subject in the country. ${ }^{6}$

\section{Brief overview of the Brazilian socio-educational system}

In Brazil, the collection and systematization of official data concerning the juvenile justice system and related public policies is insufficient. We often find comments in studies and research on the difficulties of making official data available and accessible. The National Secretariat for the Promotion of the Rights of the Child and the Adolescent, linked to the federal executive, from 2004 onwards published annually data from the national system of socio-educational assistance through the document entitled Survey of socio-educational assistance in Brazil. Although it has been drawn up and published uninterruptedly until the year 2016, the document had several formats as well as distinct data were being incorporated into the report over time so that it is difficult to extract a historical series of the same data throughout the period. One of the difficulties is precisely the disaggregation of information by sex, not adopted in different variables.

According to the last Survey (Ministério dos Direitos Humanos 2018b), which refers to the year 2016, there were 26,450 adolescents and young men and women in restrictive and custodial measures (semi-liberty, provisional incarceration and socio-educational measures of incarceration) distributed in 477 units of socio-educational service. Of the total, 419 units are exclusively male, 35 exclusively female and 23 mixed. Almost half $(45 \%)$ of the units are located in the southeast region (composed of the states of Espírito Santo, Minas Gerais, Rio de Janeiro, and São Paulo), with 14,952 adolescents and young people in restriction and deprivation of liberty. In 2006, Brazil had 15,426 adolescents and young men and women in restrictive and custodial measures, which meant an increase of approximately $70 \%$ in ten years. On average, girls represent $4.5 \%$ of the total and are the unquestionable minority in the Brazilian socio-educational system.

Since the Survey began to disaggregate data by type of offense, considering only the consummated offenses (excluding attempt), there is, on average (2012-2016): robbery

${ }^{6}$ It will be object of another reflection to indicate how the concept of gender was adopted in the dissertations and theses and how the feminist theoretical approaches chosen by the authors were presented in the final texts. At this moment of reflection, the category gender was used to find and delimitate the studies reviewed but was not the object of analysis of the article. 
(37\%), drug trafficking (24.6\%) and homicide (9.2\%). Only since 2013 have the Surveys begun to adopt the racial classification according to the Brazilian Institute of Geography and Statistics (hereinafter IBGE). On average (2013-2016) 58\% of boys and girls are black (black and brown), 23\% are white, and 1\% are indigenous and yellow. The high percentage registered in the documents as "without information" $(18 \%)$ is noteworthy, despite the importance that racial classification has for the subject. But despite this lack of information, there is no denying that punishment and lethality of adolescents and young people in Brazil are characterized by color and race. While the white homicide rate has declined, black homicide continues to grow, especially among the youth. In 2016 the black homicide rate was $40.2 \%$ against $16 \%$ of non-blacks; between $2006-2016$ the black homicide rate grew by $23.1 \%$, while non-blacks decreased by $6.8 \%$. Black women had a 71\% higher homicide rate than non-black women (Instituto de Pesquisa Econômica Aplicada - IPEA- and Fórum Brasileiro de Segurança Pública - FBSP 2018). Data on incarceration and lethality in Brazil report that racism is a substantive variable within the scope of criminal control and has promoted systematic extermination of black youth (Flauzina 2006, Senador Lindbergh Farias 2016).

\section{Methodology and general aspects of the selected papers}

Studies known as state of knowledge or state-of-the-art have a bibliographical character and assume as a challenge the systematization, mapping and discussion of academic production in different fields of knowledge (Ferreira 2002, Morosini 2015). As a stage of broader research or in-depth studies on certain topics, such as postgraduate work, the examination of knowledge production is fundamental for the breakdown of prejudices, traps that researchers fall into because they are "contaminated" by information and prior knowledge about their themes, based on "immediate appearances and partial positions" (Quivy and Campenhoudt 2005, p. 25). This rupture removes previously conceived concepts and false evidence that are no more than illusions about the understanding of certain objects of study, so that the identification of the state of knowledge is therefore the "first constitutive act of scientific procedure" (Quivy and Campenhoudt 2005). But the production of knowledge finds limitations in time and space, since the pretension to embrace everything that has been produced about a particular subject or object of study is an unrealizable task. Thus, the researcher must define aspects and dimensions of what will be privileged in the bibliographic survey in dialogue with the objectives of the proposed study.

For this article we have adopted a descriptive and analytical perspective of the scientific production of the Brazilian postgraduate programs (master's and doctorate) in dialogue with other bibliographies on the subject from both Brazilian and foreign literature. We chose to select research results that, in some way, addressed the implementation of socioeducational measures for girls, seeking to identify what works have been produced that adopted gender studies and/or feminist theoretical perspectives contributions in order to map the knowledge production and to recognize gaps to encourage new possibilities of research and analysis on the subject. We did not consider the work that has been dedicated to the implementation of socio-educational measures for adolescents and youth of both sexes, but only for girls. Intentionally we opted for works that did not draw comparisons with the boys in order to identify what was found in the research as peculiar to the execution of the measures by the girls. Therefore, when pointing out 
reflections that bring forth the situation and the approach from the boys' experience it will be in a tangential mode, only to compose the analysis regarding what is considered common in juvenile delinquency and juvenile justice.

Considering the selected sources - dissertations (master's) and theses (doctorate) inexorably the locus of data collection was the Sucupira Platform, the main reference database of the National Postgraduate System (SNPG), of the Coordination of Improvement of Higher Education Personnel (CAPES) in the country. Given previous initial reading, we knew that the period in which research on girls had begun was in the early 2000s, and so we chose to consider all the collection available on the Sucupira Platform from the beginning of the online registrations until 31 December 2017. In the search engine we used the keyword "medidas socioeducativas" [socio-educational measures] and its variations. The search considered whether the selected keyword would be in the abstract or in the keywords of the dissertations and theses. We opted for the expression "socio-educational measure" because we anticipated that this necessarily would precede the description of the socio-educational measures attributed to adolescents in the special legislation. Exemplarily, a research that adopts as a theme, subtheme, objective or object of theoretical reflections, aspects of the execution of the measure, life trajectories of the girls of the assisted liberty, community service, semiliberty or incarceration would most likely adopt the word "socio-educational measure" as antecedent of the modality of the measure if not in the keywords, certainly in the abstract. As a result of the adopted search methodology, 51 papers were found.

From the general aspects of the work it can be observed that 33 were developed in postgraduate programs of public educational institutions and the majority (36 papers) were defended between 2012 and 2017, which reinforces the recent and growing interest on girls in the field. The studies appeared in all five geographical regions of the country, ${ }^{7}$ but 24 were from the Southeast region, which may be related to the fact that it is the region with the highest percentage of adolescents and young people in the socioeducational system of Brazil. São Paulo and Rio de Janeiro were the states with the highest number of dissertations and theses on the subject, and no research was identified in 13 of the 27 states of the country's federation.

Although there were works in different areas of knowledge - ten in all - 19 were developed in Psychology, followed by Interdisciplinary programs (nine) and by Social Work programs (six); of the total, only six were from the doctoral level. This data suggests that despite the growing interest in the subject, girls are "dispersed" in the socio-educational field and the adoption of study objects that consider their particularities and experiences when reached by the juvenile justice system lacks consistency.

Some were not fully available on the Sucupira Platform or in the repository of the corresponding postgraduate program, so, in those cases the analysis was based solely on the abstract. Forty studies emphasized socio-educational measures of restriction of liberty (semi-liberty) and deprivation of liberty (provisional incarceration or incarceration), with special attention to aspects of the implementation of the socio-

\footnotetext{
7 Brazil has 26 states that consist of the federative units and the Federal District, and these are divided into five regions.
} 
educational measure of incarceration. The presented results were grouped and are better understood not as independent categories, but as results that connect and complement each other. ${ }^{8}$

\section{Main results analyzed}

Preliminarily, we point out that, regardless of the area of study, the theoretical and methodological choices, or the objective and problematization, the absolute majority of the studies were carried out through field work and in some way valued the experience of the girls in the execution of the socio-educational measure. The methods varied, but interviews with girls were the technique of data collection adopted in all studies with this approach (e.g. Hulle 2006, V.C.T.G. Almeida 2007, P. Santos 2008, M.M.C. Silva 2008, 2013, Jesus 2011, J.H. Santos 2011, J.S. Arruda 2011, Aranzedo 2012, Sousa 2012, Machado 2014, Diamantino 2015, Duarte 2016, Gomes 2016, L.C. Rocha 2016, Vilarins 2016). To listen to the girls, to consider their conceptions about the socio-educational measure and the institutions of the juvenile justice system, to know their life stories (or fragments of their life stories), to point out knowledge and skills acquired during the execution of the socio-educational measure, to identify life projects post-measure were some of the subthemes found in the dissertations and theses. All researchers justified listening as the main investigative strategy given the scarcity of work that privileged girls, the lack of knowledge about their conceptions, experiences and trajectories, and, especially, considering their secondary role and their invisibility in the juvenile justice system. The interviews ensured a sociodemographic profile, an understanding of their pathway to delinquency and their motivations or justifications for offending, an understanding of the meaning of the socio-educational measure in their lives and an evaluation of the institutions of the juvenile justice system, results that will be discussed throughout the text.

This preliminary emphasis is pertinent since the adhesion to biographical studies and studies that contemplate histories and life trajectories considering the experiences of the women and the contexts in which they are inserted are especially relevant in the studies of gender and in the studies that adopt feminist theoretical references (Harding 1998, Sardenberg 2002, Kruttschnitt 2013). Feminist theories have, from the diversity of their approaches, critiqued the way of doing science that does not consider women as subjects of knowledge and ignores their experiences as cognitive subjects. Feminist epistemologies consider that the use of the concept of gender as a social category introduces a potent analytical tool that triggers reflections in several fields of knowledge (Perrot 1995, Rago 1998). The social relations between the sexes and the construction of the perceived differences between the sexes are, therefore, important for a feminist epistemological project where the emergence of gender as a category changes conclusions and assumptions within the fields of knowledge (Haraway 1995, Perrot 1995, Harding 1998, Rago 1998, Sardenberg 2002). Not surprisingly, research on adherence to the feminist theoretical contributions began and had as an investigative locus, places occupied mostly by women or places that, occupied mostly by men, made women invisible.

\footnotetext{
${ }^{8}$ Not all 51 dissertations and theses are directly referenced. We emphasized those that presented results that dialogue with the objective of the article.
} 
Although not the main objective of the studies, a number of them dealt with the effects of institutionalization and aspects of the implementation of the socio-educational measure of incarceration, mainly focusing on Erving Goffman's concept of total institution, and on adherence to the work of Michel Foucault, especially about the technologies to domesticate and make docile the bodies through disciplinary power and biopolitics (P. Santos 2008, Sousa 2012, A.B. Arruda 2013, Coêlho 2013, Macedo 2014, Machado 2014, Duarte 2016, Gomes 2016). Thus, the practices produced in the socioeducational measure of incarceration have a special "disciplinary concern about their bodies [the bodies of the girls], with the purpose of making them useful and docile bodies, while at the same time aiming at preserving life as survival, within the space of the execution of the measure, in terms of exercise of biopolitics" (A.B. Arruda 2013, p. 154).

Some of the dissertations and theses concluded that the socio-educational measure of incarceration converges with the prison sentence for adults and elucidated the negative effects of deprivation of liberty. Likewise, they highlighted the distance between what was established in ECA and in the National System of Socio-Educational Assistance (hereinafter SINASE) regarding the pedagogical-assistance nature of the socioeducational measure and its execution which operated in a punitive dimension in an "institutional environment as a stigmatization, control and discipline space" (Coêlho 2013 , p. 21). Others also pointed out that the way the socio-educational measure of incarceration is carried out has a close relationship with the doctrine of the irregular situation and the tutelary period, characteristic of when the Minors Code was in place, which was revoked with the advent of ECA (J.S. Arruda 2011, Coêlho 2013, Machado 2014). This fact, in last instance, expresses the "failure to overcome models of repressive and correctional care (or moral reform)" which by not fulfilling the objective of the socioeducational measure contribute "to the reproduction of a daily life of rights violation and stigmatization of adolescents" (Coêlho 2013, p. 193). The girls tend to refer to the incarceration institutions as "prison" or "jail" (J.S. Arruda 2011, Coêlho 2013, Diamantino 2015, Duarte 2016) and associate the determination of incarceration as punishment for an evil that they have practiced, in direct relation to the idea of retributive justice: these results call into question the legal nature and effectiveness of the socio-educational measure, whose centrality lies in the pedagogical and educational character with the objective of autonomy building.

A single work dealt with decision-making processes and among other methodological strategies adopted in the study, we highlight content analysis to identify the judicial representation of the discourse about the application of the socio-educational measure of incarceration for girls, whose documentary corpus was composed of twenty-eight legal sentences (Machado 2014). The author identified the frequency of the elements "family", "environmental influences", "personality", "school and work" and "purpose of the measure" in the pronounced legal sentences and found that the blame on the families and the blame on the girls for family disintegration, as well as the stigmatization of their local contexts were outstanding. The lack of interest in school education or school dropout associated with the lack of work are aggravating in the history of the girls and the evaluation of their personalities, and assume nuances that are both in the past and directed toward the practice of the crime, or turn to the future, reasoning why they can still commit crime - the dangerous personality. The purpose of the socio-educational 
measure applied by judges was adopted ambiguously: as retribution to the evil practiced, or as an instrument for suppressing the deficiencies of the adolescent's socialization, hence in the cross between neutralizing risk (by arbitration) and socializing the disabled (by perversion), institutionalization is the only possible answer. The researcher concludes that perversion lies in the judicial authority that views girls as disruptive to order, as it reveals the state's inability to promote full citizenship. That is, the socio-educational measure of incarceration is determined as a late state benefit, whose judicial representation is: punish to protect. The grounds and justifications for determining the measure are engendered in a continuum of euphemistic discourse that ultimately produce the mortification of the adolescents hopes (Machado 2014). In dialogue with these results, Natália Vilarins (2016) evaluates that the lives of the girls when carrying out socio-educational measures of incarceration do not have their precariousness recognized. Privileging the theoretical formulations of Judith Butler (2006 and 2010), for whom mourning is a recognition of the precariousness of life, she argues that girls do not have their lives recognized as lives and thus are not encompassed by life-protection systems. The lives of the girls are not worth mourning, they are not recognized as lives that matter and that deserve to be lived given the threat of danger they represent. They fit into a profile of invisible people whose lives are only perceived when they become dangerous and encounter the punitive state of the juvenile justice system. When the socio-educational measure of incarceration does not reach the predicted protection and is leveled to a prison, the consequence is the non-recognition of the precariousness of the girls' lives, and that they continue to be considered lives not worthy of mourning (Vilarins 2016).

Still within this line of approach, some studies tended to highlight the incarceration institutions as masculine spaces designed for boys, relegating girls and disregarding their needs, a recurring interpretation shared by studies that approach prison establishments for women in Brazil (e.g. Lemgruber 1999, Soares and Ilgenfritz 2002, Espinoza 2004, Colares and Chies 2010, Ministério de Justiça - MJ - 2015).

Next to the above results, a group of works were dedicated to contextualize the theme and the problematization of their research showing how women and men are subject in a different way to criminal vulnerability and, therefore, subject to distinct forms of punishment considering the differences perceived between the sexes (Araújo 2004, Ramos 2007, J.S. Arruda 2011, Machado 2014, Costa 2015, Diamantino 2015, L.C. Rocha 2016). They concluded that because of the androcentrism of the Criminal Law and the institutions of the juvenile justice system, girls are relegated to the "background", not being seen, making their stories and the peculiarities of being a woman invisible. They brought forth theoretical references from criminology, notably Critical Criminology and Feminist Criminology approaches, which were triggered by the feminist critique of science elaborated during the second wave of feminism in which criminologists attempted to consolidate Feminist Criminology, a field of study dedicated to women, considering the specificities of sexual differences both as victims and perpetrators of crime.

Carol Smart, considered one of the pioneers in the feminist critique of criminology (Espinoza 2004, Daly 2006, Mendes 2014) in the mid-1970s, problematized that many criminological studies did not even mention women, or considered them insignificant, 
since the actor, the subject was always the man. Female delinquency was commonly treated as subordinate to men: the rationality, the motivation or the victim were theirs [of the men], which excluded and made invisible women who committed crime (Smart 1980). The feminist reading of criminology found space in Critical Criminology (Baratta 1999), and what interested feminist criminologists was to understand how the production and reproduction of the multiple dimensions of experience intertwined with inequalities and how they took the form of a fluid, contingent, and non-fixed social structure that would have peculiar implications for women. In this analytic perspective, feminist criminologists have examined criminal practice from a variety of positions within the structural matrix producing knowledge about women committing crimes and valuing their stories and experiences (Espinoza 2004, Daly 2006).

However, there are critical considerations that can be pointed out. For example, Adícea Castillo (2008), in addressing the work of Rosa del Olmo, reminds us that Critical Criminology in Latin America embraced class without considering sex, ignoring that a woman is subject to a peculiar social control for being a woman; and Critical Criminology has also forgotten the minors, a crucial issue given the Latin American specificities, which have placed women and minors as particularly fragile segments in the face of postcolonial structural problems (J.S. Arruda 2019). And yet, Hillary Potter (2013) emphasizes that the multiple forms of domination that black women (adult or otherwise) are subjected to in societies built on institutional racism and the patriarchal gender order require a differentiated viewpoint to be adopted in the analysis of criminal practice (delinquency) by black women and girls. For the author, the first formulations of Feminist Criminology were born from the mainstream of feminism and its early elaborations were not able to perceive the social fractures provoked by the articulation with race. Thus, despite the efforts of feminist criminologists to insert the gender category in criminological analyzes, the intersection with race remained neglected, and as black women are more vulnerable to victimization processes and tend to be the poorest among the poor (which is the case of Brazil, according to data from IBGE), the analyzes need to consider the peculiar experience of black women that crosses the differentiated and ostensible policing of the communities where most of them are inserted in with the processing and criminal procedures, marked by institutional racism. Hillary Potter (2013) calls for a necessary racial reading of Feminist Criminology leading to Black Feminist Criminology.

Nevertheless, the use of this interpretive key anchored especially on Feminist Criminology tended to consider the sexual differences as a presupposition for the differential treatment between boys and girls, but not the generational difference to bring the women in a correlative analysis. That is to say, when considering the sexual identification (women/girls and men/boys) the aspects of generational differences were ignored, transporting the explanatory capacity of the criminological theoretical approaches adopted for understanding the penal system to the juvenile justice system even though the element that distinguishes both systems is precisely the (objective) condition of the age difference. Thus, on the one hand, there are studies on the juvenile justice system and the experience of girls in the socio-educational system focused on issues of gender disregarding generation; or, when focused on the generation category, they are from an androcentric perspective and take as a starting point the experience of boys. By disregarding one category or another, the results of these studies fail to account 
for the complexity and peculiarities of being a teenage woman in the juvenile justice system, which is not the same as being a woman in the prison system or being a boy in the juvenile justice system. In addition, it is not uncommon for the category race to be forgotten or even sparsely used, even under Critical Criminology contributions (Flauzina 2006, Potter 2013).

Therefore, the concept of intersectionality presents itself as a useful analytical lens to unveil the disparities and inequalities marked by the intersection of different social categories (Collins 2015). As an analytical resource, the notion of intersectionality stresses differences within differences (Crenshaw 1991), since it seeks to identify the inequalities of power that are established within social groups that are supposed to be homogeneous. Thus, for example, there will be a difference of class, generation and race between groups of women, as well as gender, generation and class differences among black populations that can put the subjects in different positions of power. Therefore, it is said that on the theoretical level the notion of intersectionality redefines the concept of oppression. For Patricia Hill Collins (2015) there is a matrix of domination characterized by oppressions that are intersections and it is not possible to focus only on an axis of oppression or subordination; it is not enough if we consider only one category to juxtapose with one another, but rather the peculiar intersection produced among social categories (Crenshaw 2002). In the case of the juvenile justice system, the very few revised works that sought to intersect gender, race, class and generation, lacked analytical depth.

Adriana Rodrigues (2017) surveyed girls that had fulfilled a socio-educational measure of incarceration and focused on the intersection between gender and race. She pointed out the discontinuity of the offer of social protection services to those who left the socioeducational system and found that the managers and professionals of the institutions lacked knowledge about specificities of black female adolescents, highlighting the invisibility of racial and gender issues. Daiane Gomes (2016) adopted an intersectional perspective to interpret her data, using theoretical references of Brazilian black feminism, but also presented results that favor the intersection of gender and race. By assuming the objective of analyzing how gender and race specificities influenced the life trajectory of black girls and their pathway to delinquency, the author hierarchized these social categories, losing sight of the fact that it is precisely in the intersection with the other social categories that the experience of girls in crime will be constituted.

Considering the profile of girls accessing the juvenile justice system, it is well known that the large majority find several obstacles that impact their life trajectories and the analysis from an intersectional perspective contributes to recognize the particularities of the multidiscriminations that they are subject to in their concrete experiences, but that in frank adherence to the concept of intersectionality cannot enter the misconception of the selective attention of difference or of limiting the intersections to the questions of identity. It is necessary to bring the debate to the structural level by considering gender, race, class and generation as social categories, so that differences and power relations are not produced only in the context of social interactions (McCall 2005).

The search for understanding the motivations and justifications for offending as a general objective interested some of the researchers, mainly in postgraduate programs in psychology. The conclusions were basically founded on the following perspectives: 
motivations related to the need for sustenance or the desire to acquire material goods and to consume entertainment (V.C.T.G. Almeida 2007, Diamantino 2015, L.C. Rocha 2016); gaining fame, social recognition and power (Diamantino 2015); risk as a pleasure (Hulle 2006); and influence of intimate peer relationships for initiating and continuing offending (Silveira 2013, T.L. Silva 2014, Gomes 2016). In the studies reviewed, the types of offenses practiced in association/love partnership predominantly were crimes against property (especially thefts and robberies); drug trafficking and related conducts.

In the international literature, relatively recent studies that have focused on analyzing the trajectories of girls and young women with experiences in institutions similar to socio-educational incarceration institutions have also tried to understand the main motivations and "triggers" that led to offending. Vera Duarte (2012) has identified that as a dimension of the transgressive paths, motivations may be in the "running away from family problems", which in escalation can lead girls to a street life and feelings of revolt, situations in which the transgression is related to the management of negative feelings; the "influence of external factors" (boyfriends, friendships, drugs), linked to pleasure, fun and group membership; "experimentation", testing of limits and rebellion, tempted by risk-adventure, pleasure and fun; and "occasional situations" in which the offense is an exception. Raquel Matos (2008, pp. 177-178) identified three basic profiles: "crime as a way of life", in which recidivism and extensive criminal history predominate, marked by crimes against property and as a means of heavy drug use; "crime as a business", seen as a "business opportunity" where girls "move and relate, and that allow them to overcome financial difficulties" - almost always by drug trafficking and in association with other people; and "crime as an exception", cases where offending was an isolated act and were almost always violent crimes motivated by exceptional situations - in these cases women rarely have a criminal history. Jacinthe Mazzocchetti (2005) highlights family problems; the influence of peers and marginalized socialization in which groups of adolescents from certain localities are found; and rebellious trajectories.

These categorizations include the multifaceted character and the heterogeneity of the "triggers" that lead girls to offending - just as it is in boys' trajectories. If we turn to official data and research that focused on the life trajectory of boys (Assis 1999, Secretaria de Direitos Humanos da Presidência da República 2012, 2014, 2015, Ministério dos Direitos Humanos 2017, 2018a, 2018b) who accessed the juvenile justice system, we will identify similar profiles, mainly marked by poverty, school drop-out and age-grade distortion, and racial condition; that is, boys and girls who access the juvenile justice system share problems and characteristics that lead to criminal vulnerability and make them more easily selectable for punishment. The crucial difference in the vulnerability of girls is the greater lack of sexual protection (they are more vulnerable to sexual violence), a type of violence that refers to the patterns of gender social relations (Matos 2008, Duarte 2012, Chesney-Lind and Shelden 2014, Gallego 2017).

Only one selected work specifically and directly associated the pathway to delinquency "as a result of family disruption" (V.C.T.G. Almeida 2007, p. 45). On the influence of family dynamics, some studies conclude that girls tend to be more impacted by disorganized family contexts, characterized by the weaknesses of the main instance of informal social control (Giordano et al. 2002). In such approaches there is a certain 
relation between the family context, the experience of victimization in the family or lack of care and criminal activity, especially for girls. Raquel Matos (2008, p. 50) understands that this type of argument is based on etiological-explanatory approaches to female criminality, since it maintains the underlying idea that under equal family conditions, girls would be "naturally more vulnerable to deviance, being that this vulnerability is related to characteristics that are intrinsic to women". If we consider patterns of the patriarchal gender order and the way girls are socialized it can be considered that they will suffer more from domestic and household tensions because they tend to be more present in the domestic and family environment than boys. The hypothesis pointed out by Maria João Carvalho (2003) and corroborated by Vera Duarte (2012) is that boys are precociously subject to formal social control whereas girls are the target of intervention when their criminal offenses increase visibility which is, for the authors, associated with the severity of the act or violence employed in the offense.

In dealing with primary and secondary socialization processes of girls who carried out a socio-educational measures of incarceration in a state in the southern region of the country, Rochele Fachinetto (2008) found results that go in the same direction: among the girls, those who had a greater socialization in the private sphere, the offense or penal contravention committed was a onetime act, none of them were recidivist, and the offense was analogous to crimes against persons - in accordance to what Raquel Matos (2008) and Vera Duarte (2012) considered, respectively, as crime as an exception or as a circumstantial transgression, considering their crime categorizations. On the other hand, "those whose socialization occurred mostly on the streets and with less incidence of informal social control, are those who committed crimes mostly against patrimony and were recidivists" (Fachinetto 2008). In dialogue, it can be said that low incidence of crime commission by women and girls is a result of the efficiency of informal social control, privileged in primary socialization, because "female socialization acts as a factor that inhibits and protects women from entering the world of crime more than they inhibit and protect men" (Fachinetto 2008, p. 103). This interpretation is shared by Elena Larrauri (2008) who considers that the reasons why women commit less crime are linked to the fact that the informal social control exercised over them is greater than that exerted on men, imposing limits on their participation in the public sphere, subject to formal social control. But it is important to be cautious when dealing with the impacts caused by family dynamics and primary socialization, especially in the Brazilian case. It should be borne in mind that not infrequently, reflections on the concept of family dysfunction/disorganization attribute the blame on women, especially in the case of poor single-parent families headed by women (J.S. Arruda 2019), which, in Brazil, are mostly black women (Marcondes et al. 2013).

Returning to the review of the studies that focused on the motivations and justifications for offending, at some point, either as a composition of the problem or as a digression, some questioned whether the girls are more violent nowadays or if they commit offenses of the same type as the boys, especially regarding the use of violence. It is obvious that, considering that there are fewer girls in the Brazilian socio-educational system (4.5\%), that they are involved in a smaller number of offenses considered to be violent; however, qualitatively (considering the type of offense) research has revealed that girls commit violent offenses just as boys (M.M.C. Silva 2008, 2013, J.S. Arruda 2011, Mendes 2012, Diamantino 2015, Duarte 2016), especially those who are sentenced to socio-educational 
measures of incarceration. Except for offenses similar to crimes against sexual dignity, commissioned research corroborates the understanding that girls commit the same offenses as boys, with or without the use of violence (CNJ 2015, Diniz 2017).

According to Dora Diamantino (2015), the narratives of the girls studied indicate that it is not correct to see them only as passive victims, for, although they are "still victims of violence, they also subvert the institutionalized social roles in the patriarchal culture to be protagonists in the perpetration of violence" and, in the same way as men, "they are recognized in these contexts as perpetrators of violence and, therefore, they arm themselves with weapons, engage in fights, carry out thefts, robberies, homicides, or sell and transport drugs" (Diamantino 2015, p. 160). Although the analysis has sustained the use of violence from the antagonism victim versus agent, it is relevant to note that the girls did not use violence to be like boys, but as a way of being girls. Similarly, Ana Mendes (2012, p. 119) has identified that girls do not claim a femininity found in traditional gender patterns, but also do not necessarily want to be like boys; they lived a way of being girls with trajectories characterized by the "plurality/diversity of ways of living their femininity".

In a similar perspective, María Beltrán (2010) states that the use of violence by young women in a poor neighborhood of Buenos Aires influenced and contributed to the construction of their femininity, rejecting the idea that violent practices and the use of violence are linked to masculinity and the ones practicing various types of violence were seeking to "act like men". In a survey conducted with youth gangs in the Federal District, the violent behavior of girls was a form of identity affirmation, expression and recognition, and even though "these practices have traditionally been contrary to gender expectations, they do not contradict the current dictates of femininity", because "violence has become something progressively incorporated into feminine identities, corresponding to a employed language" by them, especially in the "search for social visibility and recognition" (Abramovay and Fefferman 2014, p. 59). Therefore, there is no difference in the etiology of forms of delinquency, since boys and girls share the same tendencies and, just as it is relevant to consider that different socialization processes will produce different experiences, it is important to consider the difference in the ways in which the criminal trajectories are experienced (Carvalho 2014). In other words, if there is no substantial difference in why they engage in offending and what crimes they commit, it is pertinent to understand how they accomplish crime (Miller 2002).

Vera Duarte (2012) points out the concept of "doing gender", preferentially used by Jody Miller $(2002,2014)$ in the study of female juvenile gangs as an explanatory key to genderize the trajectories of girls in offending. Initially adopted by Candance West and Don Zimmerman (1987), "doing gender" considers that gender is conceived as an embodiment or embodied production in everyday interactions. From an ethnomethodological approach, gender is considered to be "a situated doing, carried out in the virtual or real presence of others who are presumed to be oriented to its production", perceived as a characteristic of social relations and "both as an outcome of and a rationale for various social arrangements and as means of legitimating one of the most fundamental divisions of society" (West and Zimmerman 1987, p. 126). Without adopting the usually common difference that distinguishes sex from gender, where the former is linked to nature and the latter to culture, in this approach there is a distinction 
between sex, sexual category and gender. "Sex is a determination made through the application of socially agreed upon biological criteria for classifying persons as females or males" and sexual category is what is claimed by individuals even though they lack sexual criteria. On the other hand, gender "is the activity of managing situated conduct in light of normative conceptions of attitudes and activities appropriate for one's sex category" (West and Zimmerman 1987, p. 127), so that gender activities arise to reinforce sex category belonging.

Gender is created through social interaction at the same time as it structures and organizes the social interactions, not as a set of characteristics or variables, but as a product of social actions. "Doing gender" emerges as an interesting analytical tool to overcome the agency/structure division and to problematize girls and women not only as victims by virtue of gender and gender identity, but as subjects that from gender action can consciously drive their social practices to meet social norms imposed on them or their sexual category, as well as to resist them (Miller 2014). Following the above, it is relevant to understand the circumstances in which violence was used by girls considering the objectives and motives for that particular action, taking into account that the actions are not dissociated from the social contexts from which the use of violence emerged as a possible resource. ${ }^{9}$

Themes that address gender relations, gender identity and sexuality are still incipient in research on the juvenile justice system. There are even fewer studies that focus on issues specific to the female sex, such as pregnancy, puerperium and cohabitation with children during the socio-educational measure. One of the studies identified aimed at investigating the meanings of the experience of motherhood of adolescent mothers who were in socio-educational measure of incarceration away from their children and emphasized how the socio-educational measure interferes negatively on the bond between mother and child, reinforced by the distance between the city of origin of the girl and the location of the institution (N.O.G.L. Almeida 2011). The study also emphasized the participation of the girls' partners and fathers of their children in delinquency/crime.

Impeded from conducting field research by the management of the socio-educational incarceration institution located in the State of São Paulo, Maria Silva (2016) conducted interviews with a young woman who had already completed the socio-educational measure of incarceration. Even with the limitations of access to data, the results found are relevant to direct further research, especially from gender studies perspectives: maternity as a protection factor from future offending, and the pedagogical intervention on how to be a "good mother", based on stereotyped conceptions of the role of women and marked by the importance of motherhood in the constitution of a feminine identity (M. Silva 2016).

\footnotetext{
9 The formulations on the concept of intersectionality referred to previously direct critics precisely to the theoretical formulations such as "doing gender" and "doing difference". Leslie McCall (2005) argues that, regardless of the particularities of each theoretical formulation, both conceive the differences of gender, class and race as the production of interaction processes that will result in hierarchization in the power relations without considering them at the structural level, which is the privileged space for the establishment of social inequalities.
} 
There is a reference to motherhood as a resource for adult female resocialization (Cúnico et al. 2015) or as a "rescue" or "salvation" from the criminal life (MJ 2015). Another issue of relevance on the subject is the cohabitation of adolescent and adult women with their children in deprivation of liberty institutions. It is the right of the child and of the mother to stay together in deprivation of liberty institutions, ${ }^{10}$ but the uncomfortable and unhealthy facilities put in jeopardy the principle of the best interest of the child and put in question what is the best option to adopt: to ensure cohabitation between mother and children for more or less time.

As a result of mother and child living in institutions of deprivation of liberty, there are also processes of hypermaternity, characterized by constant contact between mother and child which, among other effects, restricts the participation of the woman/adolescent in institutional activities; and of hypomaternity, when the child leaves the socioeducational institution/prison and is placed with the family or an institution that shelters these children during the period of incarceration of the mother (MJ 2015). It is true that if in the prison system the information about the existence of pregnant women, women who are puerperal and living with their children is not precise (MJ 2015), there is no mention at all of such information in official documents about the socio-educational system in Brazil.

For specific issues about "being a woman" in prison, it is worth remembering that the creation of women's prisons in Brazil was a very peculiar combination of religious moral precepts and the postulates of the Classical and Positive School of Criminal Law. Female criminality was understood as a deviation from the social role intended for women that should be corrected and contained, and therefore, female prisons aimed to recover characteristics (values, behaviors) that were considered typical of the female sex (Andrade 2011). It is no coincidence that the correctional houses maintained by the Bom Pastor congregation were responsible for the administration of women's prisons in Latin America until the 1980s, as in the case of Argentina (Aguirre 2009, Andrade 2011). Unlike the proposal for men, the historiography of prisons indicates that women were not treated militarily, but rather in a "loving and maternal environment" (Aguirre 2009, p. 51). Seen not as "delinquents", but as "occasional offenders", victims of moral weakness resulting in irrationality and lack of intelligence, women prisoners were not of great concern to the state and, consequently, religious institutions functioned autonomously. Guided by the "house-convent" model, the prisoners "were forced to work on tasks that were 'proper' for their sex (sew, wash, cook)" that could be extended to domestic work "in the homes of decent families for the purpose of completing their 'recovery' under the supervision of the bosses" (Aguirre 2009, p. 52).

Even today, the influence of these skills is evident in women's prisons and in women's juvenile justice system incarceration institutions. Informal knowledge that guides the use of motherhood as a resocializing character is not far from the content of the pedagogical activities developed in the incarceration institutions. The pedagogical activities have special relevance in the socio-educational measure, given its hybrid legal

\footnotetext{
${ }^{10}$ In the socio-educational measure of incarceration the cohabitation of mother and child is foreseen during the breastfeeding period (article 63, § 2, SINASE). ECA (article 54, item IV) and SINASE (article 49, VIII) guarantee the right to daycare for children of adolescents carrying out socio-educational measures of incarceration.
} 
nature due to the coexistence of the coercive-penal character regarding the determination, but pedagogical-assistance regarding the execution. Regular schooling and insertion in workshops that contribute to the professionalization of boys and girls are conceived as fundamental in the socio-educational process. But the activities offered in the girls' institutions identified in the reviewed studies are courses in sewing, hairdressing, handicrafts, baking, manicure and pedicure: reproductive activities and activities that reinforce the traditional sexual roles and considered as "typically" feminine were unanimously highlighted by the works that emphasized the activities (P. Santos 2008, Sousa 2012, W.L. Rocha 2013, G.K.C. Silva 2017). Finally, these are activities that do not fulfill the right to professionalization and function as mere recreation or as reproducers of cheap labor not impacting on the construction of a life project and in the real conditions of insertion in the work world after the completion of the measure.

Another relevant point on the reflections on pedagogical practices was the absence of a planned routine of activities in the incarceration institutions (P. Santos 2008, Diamantino 2015). Despite what was prescribed as a pedagogical proposal and what had been planned in the Individual Assistance Plan, the activities in the institutions were unpredictable and characterized by improvisation. ${ }^{11}$ The focus on restraint and security is an obstacle to pedagogical activities, whose adherence is often only an opportunity to occupy time (Fachinetto 2008, P. Santos 2008, J.P. Arruda 2011, Diamantino 2015). These characteristics took on more serious contours when it came to regular school: fragile curriculum, small number of hours and unprepared teachers to work in an incarceration institution. The regular school in the institution was, finally, merely instrumental ( $\mathrm{P}$. Santos 2008). For Pollyana Santos (2008, p. 160), the fragility of the pedagogical activities and the centrality on restraint reinforced the girls' distancing from the objectives of the socio-educational measure. Through interviews with the girls, the author identified that the most significant development processes during the execution of the measure were related to the cohabitation with their peers in the institution, that is, it was among them that they learned what was relevant for life during the execution of the measure and after. ${ }^{12}$

While addressing the institutional dynamics, many studies highlighted conceptions with a strong moral weight in the work of the professionals, stereotyped views on girls'

\footnotetext{
${ }_{11}$ Briefly, the Individual Assistance Plan is an obligatory pedagogical instrument that must be elaborated together with the assistance staff, the girls and their families, containing the planning of actions, goals and commitments for the execution of the socio-educational measures (see article 52 and following articles, SINASE).

12 The work of Wânia Rocha (2013) stands out because it was developed combining arts and education and for bringing education policy focused on ethnic-racial relations in the socio-educational context. The author presented positive aspects of the adoption of music as a link between educational and pedagogical activities in the socio-educational measure of incarceration. She pointed out the importance of musical activities for making possible the "establishment of bonds, and then, enabling other structured processes of development," referring to pedagogical practices as a whole in the institution (W.L. Rocha 2013, p. 95). The pedagogical-musical activities were based on the guidelines established by Law $\mathrm{n}^{\mathrm{o}}$ 10,639, of 9 January 2003, that established the obligation of the teaching of the Afro-Brazilian History and Culture in the official curriculum of the teaching network. The author makes a relevant record about resistant demonstrations by girls and professionals who are adherents of neo-Pentecostal religions who refuse to participate in the activities due to prejudice towards African-based religions, stressing the importance of discussing ethnicracial relations and regular education in socio-educational assistance institutions as a strategy to combat institutional racism (Arruda and Figueiredo 2018).
} 
delinquency and the lack of preparation to deal with gender and sexuality issues (Sousa 2012, Coêlho 2013, Leite 2013, Costa 2015, Diamantino 2015, L.C. Rocha 2016, G.K.C. Silva 2017).

Studies that centrally address issues related to gender identity and the exercise of sexuality in socio-educational incarceration institutions begin to emerge timidly at the end of the first decade of the 2000s. A few studies have been identified with such centralities, but in different perspectives (Bassi 2011, Silveira 2013, Barbosa 2016, L.C. Rocha 2016).

From the life trajectory of transvestite and transgender adolescents who were in the provisional incarceration institution of the city of Recife, capital of the State of Pernambuco, Maria Barbosa (2016) identified that being transvestite or being transgender was an aggravating factor to criminal vulnerability. She highlighted the total disregard of their life trajectories by the institutions of the juvenile justice system as to the diversity of gender identities, while aligning decision-making (in particular, the determination of the sentence) only to the recognition of the biological sex. For the author, it is as if the condition of subject of rights and of integral protection projected in ECA did not include transgender and transsexual adolescents; that is to say, as if being a person in disagreement with heteronormativity obscured their condition of a peculiar person in development. Thus, transgenders and transvestites were referred to male incarceration institutions and were "forced to decharacterize themselves as women to be framed in a "male'" profile and forced to give up their sexuality and gender identity to fit a male performance: no women's clothing, cutting their hair - failing to "partially exist" (Barbosa 2016, p. 158).

However, we ponder that the disregard of the principle of integral protection does not only happen in the case of transgender and transvestite adolescents and young people. Orbiting in the juvenile justice system is knowledge that builds a privileged profile of the punishable adolescent, and due to the profile that certain subjects fit into, the process of criminalization happens regardless of criminal conduct. In these cases, "the transgression, whose offense is socially justifiable, slips into the subjectivity of the transgressor and into their individuality, reifying it socially as a character or inserting them into a negative social type" (Misse 1999, p. 70, italics in original). The process of criminal subjection inserts the individual into a particular social type but is extended to certain individuals when they have "attributes that are similar or related to the accused social type" (Misse 1999, p. 70). In this situation, being a transgender or transvestite being a "character of social accusation" (Misse 1999, p. 21) - may enhance criminal subjection, but body signs that signify social danger are easily found in poor urban and predominantly black adolescents and youth, social groups to which the juridical-social protection of the doctrine of integral protection is systematically disregarded. Therefore, it is not the disagreements with heteronormative and heteroperformative patterns that will abolish the condition of a subject of rights and the peculiar condition of the developing person inserted in the doctrine of integral protection, but rather, the criminal subjection. Nevertheless, once accessed by the juvenile justice system and punished with a deprivation of liberty measure, being transvestite and being transgender will produce by the mortification of the self (Goffman 1974) a rational process of character destruction of identity and personal disfiguration that will be peculiarly characterized by the 
intelligible body and challenge the order of gender that must be erased and made invisible - or cease to exist partially, as Maria Barbosa (2016) concluded.

A single selected work has taken as its theme youth gangs and gender relations. The author analyzed gender and sexuality relations within two urban gangs that dispute drug trafficking in the city of João Pessoa, the capital of the State of Paraíba - the Okaida and the Estados Unidos - from the narrative of adolescents who are carrying out a socioeducational measure of incarceration. In order to stay or become cumades, or to rise and not be considered novinhas, the gang imposes rigid rules regarding the girls' sexual behavior (L.C. Rocha 2016). ${ }^{13}$ They recognize that they play less prestigious roles in the gangs because they are women, but at the same time, they seek to reduce this distance, and, to be sentenced with a socio-educational measures of incarceration makes the internal ascension in the gang a concrete possibility.

In the gangs girls are divided in cumades and novinhas: the former is a gang worker and needs to be respectable, cannot engage in random relations, cannot have an affectionatesexual life permeated by the exchange of partners, as well as it is advisable to date a member of the gang; the novinhas on the other hand are the girls in the groups' area of influence, but are not workers - most of them only date the boys in the gang and are not respected internally. But cumades and novinhas are situational positions, because they depend on the girls' behavior, their dedication to the gang and the respect of the imposed rules. To seek space in the gangs, girls enter a game of submission and transgression that at one moment use feminine attributes, and at another manipulate their sexuality to maintain or change their status. Aware that there is no female leadership in the gangs, their purpose is to "become an adult cumade" and a sentence to a socio-educational measure of incarceration is proof of maturity in the "wrong life": as a "rite of passage" the socio-educational measure of incarceration "appears as a demonstration of strength that brings prestige" (L.C. Rocha 2016, p. 126). In the institutional daily life, they strengthen themselves with their peers and they break the heteronormative patterns imposed by the gang by having relationships with other girls (homosexuality is forbidden in the gang), in an endless negotiation between resistance and submission to the rules of the group. Put in another way, it can be said that they "do gender" and direct their actions according to their interests, managing femininities to consolidate their spaces in the gang (Miller 2014).

Regarding sexual life and intimate-affectionate relationships, these are formally forbidden in the socio-educational incarceration institutions throughout the country (CNJ 2015). Usually the prohibitions are expressed in the internal regiments of the incarceration institutions, but it is common knowledge that, regardless of these regiments, intimate sexual activity among adolescents happens. What tends to occur is the omission by managers and staff regarding these relationships in both masculine and feminine incarceration institutions, despite the differences in understandings and in manifestations of sexual activity among boys and among girls. Sexual activities among boys tend to be understood as an expression of violence, whose motivation has to do

\footnotetext{
${ }^{13}$ Cumade is a jargon for the word comadre, which means godmother of a person baptized or christened. The expression is used as a native category to refer to partner or companion of the gang. Novinha is a girl under the age of 18 , considered inexperienced. In the empirical reality investigated it meant girls of little prestige to members of the gang.
} 
with the restriction of the possibility of having heterosexual sexual relations; or, if it is a result of desire among them, it is very discreet and veiled; on the other hand among girls, lesbian relationships tend to be ostensible and recognized by professionals, but as a manifestation of lack of affection and solitude. However, the conclusions presented by Jalusa Arruda (2011) and Joana Duarte (2016) recognize the expressions of affection and intimacy between girls as an expression of desire and the exercise of sexuality, as opposed to interpretations that see the relationships and sexual intimacy between them as a means of adapting to the deprivation of liberty or the result of the impossibility of establishing heterosexual relationships (Assis and Constantino 2001, Souza 2014). Another argument is that the tacit permission of relationships between girls has to do with the fact that sex between women is understood to be harmless and not recognized as "sex" by the absence of a penis. Heteronormative formulations on the exercise of sexuality desexualize lesbian intimate relationships and ignore the implications of the relationships between them during incarceration (J.S. Arruda 2011).

In institutional dynamics guided by heteronormativity (Coêlho 2013) there is a constant attempt to feminize space, either by the type of pedagogical activities or by the "decoration of the environments in shades of pink and purple, with floral arrangements, bows and hearts" (Coêlho 2013, p. 197), decorated as a doll house (Fachinetto 2008), since "if they commit crime because of the lack of 'femininity' or an excess of 'masculinity', 'feminizing' them would thus resemble 'undelinquentize' them" (Coêlho 2013, p. 198). In this context, lesbian relationships are either desexualized, as stated above, or heavily prohibited (Coêlho 2013, M.M.C. Silva 2013, L.C. Rocha 2016). As an example, in the state of Paraíba, any kind of more intimate contact between girls was prohibited, even as mere manifestations of affection, such as hugging one another; the relocation of the girls into different rooms was constant and one of the rules of the house was to forbid girls from being called "sisters or mothers" (L.C. Rocha 2016, p. 104). The treatment given to lesbian girls, especially masculinized ones (L.C. Rocha 2016), was much more rigorous, with control and punishment directed at them manifested by medical-pathological and moral discourses, in a combination that tended to result in high medicalization and application of internal sanctions, especially those known as isolation ${ }^{14}$ (J.S. Arruda 2011, Duarte 2016).

It is a fact that one cannot ignore the importance of sexuality in the daily life of incarceration institutions. The socio-educational measure of incarceration produces different sexualities and ways of exercising them, and everything that involves the expressions and the exercise of sexuality impacts on the execution of the socioeducational measure and becomes fundamental to understand the functioning of the custodial institutions. As a device, sexuality works for the management and control of bodies that, from a biopower perspective, classify legitimate and non-legitimate ways of living sexuality (Foucault 1999) and in the case of adolescents it is aggravated by the non-recognition of autonomy for the exercise of a sexual life.

\section{Final Comments}

In general, the analyzed studies adopted few foreign theoretical references and no comparative empirical studies were found which could have offered more

\footnotetext{
${ }^{14}$ In this interpretive line it is suggested to verify: J.S. Arruda 2017 and J.S. Arruda et al. 2018.
} 
comprehensive analytical results and dialogued with social realities similar to Brazil. It is opportune to create collaborative research networks that focus on the juvenile justice system and on girls' punishment policies that can provide further readings of our reality as well as provide comparative studies especially in Latin America. Additionally, it is necessary to open paths for reflections that discuss criminality from decolonial references and question the construction of social categories such as gender and problematize the sociology of punishment itself from other epistemological perspectives.

In Brazil, the first widely known research on the application of the socio-educational measure of incarceration for girls is recent and was carried out in five socio-educational institutions, each located in one of the five geographic regions of the country (Federal District, Pará, Pernambuco, Rio Grande do Sul and São Paulo) (CNJ 2015). The results of the revised work are also distributed in the five regions and most of them are dedicated to aspects of the implementation of the socio-educational measure of incarceration which coincide with the results of the research carried out by the National Justice Council $(\mathrm{CNJ})$. Part of the panorama drawn from this research ${ }^{15}$ presents the tension between the principles of juvenile justice versus mere punishment that is embodied in violations of the adolescents and juvenile offenders' rights, especially of those carrying out socioeducational measures of incarceration. This tension is shared with the boys who are deprived of their liberty in institutions across the country. Both masculine and feminine, the incarceration institutions make the socio-educational measures of incarceration "just like a prison sentence" (CNJ 2015).

The results of the empirical research studies analyzed indicate that the guiding principles of the doctrine of integral protection that are contained in the national and international norms ratified by the Brazilian state that refer to the theme gender and juvenile justice have not been applied to adolescent female authors of crime, especially in the institutions for deprivation of liberty. ${ }^{16}$ Violations of the law are constant, both in the scope of the socio-legal protection and in the execution of the measure itself. If boys and girls share part of this scenario, in problematizing contexts from gender relations perspective, it may not be possible to affirm that they are more harshly punished, but there is no doubt that there is a peculiar mode of punishment directed to girls because of the perceived differences between the sexes. It is from this recognition and from the fissures produced both in the juvenile justice system itself and in the production of knowledge about girls that new research proposals must follow.

Thus, in the light of the results of the bibliographical review and in dialogue with broader research on the subject, a possible path for new studies is to follow the leads about the peculiarities in the way in which the punitive practice executed in the institutions of the juvenile justice system operate regarding girls. Studies produced so far construct a certain diagnosis about the situation of girls in the socio-educational

\footnotetext{
${ }^{15}$ For a synthesis of the panorama of the situation of girls in the socio-educational system in Brazil see CNJ 2015, pp. 207-212.

${ }^{16}$ Especially the United Nations Standard Minimum Rules for the Administration of Juvenile Justice (The Beijing Rules), the United Nations Guidelines for the Prevention of Juvenile Delinquency (The Riyadh Guidelines), United Nations Rules for the Protection of Juveniles Deprived of their Liberty (The Havana Rules), and the United Nations Rules for the Treatment of Female Prisoners and Non-Custodial Measures for Women Offenders (The Bangkok Rules).
} 
system, especially in the socio-educational measure of incarceration, which allows us to identify crucial points of punishment directed toward girls and which happen precisely because they are teenage women in the juvenile justice system.

Without pretense of exhaustion, but with the commitment to be propositional, we suggest that studies of the Brazilian juvenile justice and socio-educational systems that are dedicated to reflect on the punishment of girls, both on the imposition and on the execution of socio-educational measures that adopt feminist and gender studies theoretical perspectives, consider the intersection with class, race and generation. In this perspective, themes that might be of interest to investigate and analyze are: aspects and implications of mental health, mental suffering and psychiatry; maternity, mothering and cohabitation with children; discourses and legal practices; the action of the public security agents; gender identity and the exercise of sexuality; guarantee and protection of sexual and reproductive rights; patterns of femininity and masculinity; perspectives and alternatives after the completion of the measures; investment of the state entities in the programs and services of the institutions (physical structure, allocation of financial resources, budget, staff, etc.); history of sexual violence (domestic, intra-family or commercial); racial relations and institutional racism; pedagogical practices, schooling and professionalization; strategies of resistance, insubordination and non-subjection of girls while carrying out the measure; and practices and intervention models identified as successful and exemplary.

Certainly, these are subjects that unfold into a range of research possibilities and in the construction of objects of study that, in the Brazilian context, must still consider the existence of immense cultural and regional diversity; this is a task that is set, and that we must, with feminist-political engagement, develop.

\section{References}

Abramovay, M., and Feffermann, M., 2014. Novas feminilidades e gangues em Brasilia. In: V. Duarte and M.I. Cunha, eds., Violências e delinquências juvenis femininas: gênero e (in)visibilidades. Vila Nova de Famalicão: Húmus, pp. 41-62.

Aguirre, C., 2009. Cárcere e sociedade na América Latina, 1800-1940. In: C. Maia et al., eds., História das prisões no Brasil. Rio de Janeiro: Rocco, pp. 9-77.

Alvarez, M.C., Lourenço, L.C., and Tonche, J., 2017. A “experiência precoce da punição": justiça juvenil, adolescentes em conflito com a lei e instituições de internamento. Revista Plural [online], 24(1), jan/jun, pp. 1-10. Available from: https://doi.org/10.11606/issn.2176-8099.pcso.2017.137496 [Accessed 18 October 2018].

Andrade, A.P. de, and Machado, B.A., 2017. Justiça e processo penal juvenil: paradigmas, discurso jurídico e o modelo brasileiro. In: A.P. de Andrade and B.A. Machado, eds., Justiça Juvenil: Paradigmas e experiências. $1^{\text {st }}$ ed. São Paulo: Marcial Pons / Brasilia / DF: Fundação Escola Superior do Ministério Público do Distrito Federal e Territórios.

Arruda, J.S. de, 2017. Medicalização e controle dos corpos femininos na execução da medida socioeducativa de internação. In: M. de O. Pereira and R.G. Passos, eds., 
Luta antimanicomial e feminismos: Discussões de gênero, raça e classe. $1^{\text {st }}$ ed. Rio de Janeiro: Autografia, pp. 169-184.

Arruda, J.S. de, 2019. Apontamentos sobre a punição de meninas no sistema socioeducativo. In: A. Gostinski, C. Bispo and F. Martins, eds., Estudos feministas por um direito menos machista (vol. 4). $1^{\text {st }}$ ed. Florianópolis: Tirant lo Blanch, pp. 175-192.

Arruda, J.S. de, and Figueiredo, O.V.A., 2018. Breves considerações sobre medida sobre socioeducativa e formação de professores. Revista Com Ciência [online], 3(1), dez. 2018, pp. 68-76. Available from:

http://www.revistacomciencia.com/artigos 2018/Artigo 8.pdf [Accessed 20 December 2018].

Arruda, J.S. de, Carvalho, N.S., and Costa, J.C., 2018. Experiências lesboafetivas por adolescentes e jovens privadas de liberdade. Revista Áquila, ano IX, nº ed., jan/jun, pp. 66-72.

Assis, S.G., 1999. Traçando caminhos em uma sociedade violenta: A vida de jovens infratores e de seus irmãos não-infratores. Rio de Janeiro: Fiocruz.

Assis, S.G., and Constantino, P., 2001. Filhas do mundo: Infração juvenil feminina no Rio de Janeiro. Rio de Janeiro: Fiocruz.

Baratta, A., 1999. O paradigma do gênero: da questão criminal à questão humana. In: C.H. Campos, ed., Criminologia e feminismo. Porto Alegre: Sulina, pp. 19-80.

Beltrán, M.A., 2010. Criminología feminista. Estado del arte y presencia en Latinoamérica. VI Jornadas de Sociología de la UNLP, 9 y 10 de diciembre de 2010, La Plata, Argentina: Memoria académica [en línea]. Universidad Nacional de La Plata, Facultad de Humanidades y Ciencias de la Educación, Departamento de Sociología. Available from:

http://www.memoria.fahce.unlp.edu.ar/trab eventos/ev.5515/ev.5515.pdf [Accessed 12 December 2017].

Bourdieu, P., 1989. O poder simbólico. Trans.: F. Tomaz. Rio de Janeiro: Bertrand Brasil.

Butler, J., 2006. Vida precaria: El poder del duelo y la violencia. Buenos Aires: Paidós.

Butler, J., 2010. Marcos de guerra: Las vidas lloradas. Madrid: Paidós.

Carvalho, M.J.L. de, 2003. Entre as malhas do desvio: Jovens, espaços, trajectórias e delinquências. Oeiras: Celta.

Carvalho, M.J.L. de, 2014. Pelos (outros) mundos sociais da infância: territorialidade, género e delinquência. In: V. Duarte and M.I. Cunha, eds., Violências e delinquências juvenis femininas: Gênero e (in)visibilidades. Vila Nova de Famalicão: Húmus, pp. 95-114.

Castillo, A., 2008. Rosa del Olmo: los problemas de género en su obra. Revista Venezolana de Estudios de la Mujer [online], 13(31). Available from: http://www.scielo.org.ve/scielo.php?script=sci arttext\&pid=S131637012008000200016 [Accessed 12 December 2017]. 
Chesney-Lind, M., and Pasko, L., eds., 2013. Girls, Women and Crime: Selected Readings. Los Angeles: Sage.

Chesney-Lind, M., and Shelden, R., 2014. Girls, Delinquency and Juvenile Justice. $4^{\text {th }}$ ed. Oxford: Wiley \& Blackwell.

Colares, L.B.C., and Chies, L.A.B., 2010. Mulheres nas so(m)bras: invisibilidade, reciclagem e dominação viril em presídios masculinamente mistos. Estudos Feministas [online], no 18, maio-agosto, pp. 407-423. Available from: https://doi.org/10.1590/S0104-026X2010000200007 [Accessed 12 December 2017].

Collins, P.H., 2015. Em direção a uma nova visão: raça, classe e gênero como categorias de análise e conexão. In: R. Moreno, ed., Reflexões e práticas de transformação feminista. São Paulo: Sempreviva Organizacão Feminista.

Conselho Nacional de Justiça, 2015. Dos espaços aos direitos: A realidade na ressocialização na aplicação da medida socioeducativa de internação das adolescentes do sexo feminino em conflito com a lei nas cinco regiões do país [online]. Brasilia: Conselho Nacional de Justiça. Available from:

http://www.cnj.jus.br/files/conteudo/destaques/arquivo/2015/06/cb905d37b1c494f 05afc1a14ed56d96b.pdf [Accessed 12 December 2018].

Crenshaw, K., 1991. Mapping the margins: intersectionality, identity politics, and violence against women of color. Stanford Law Review [online], 43(6), pp. 12411299. Available from: http://doi.org/10.2307/1229039 [Accessed 11 December 2018].

Crenshaw, K., 2002. Documento para o encontro de especialistas em aspectos da discriminação racial relativos ao gênero. Estudos Feministas [online], 10(1), pp. 171-188. Available from: http://www.scielo.br/pdf/ref/v10n1/11636.pdf [Accessed 12 December 2018].

Cúnico, S.D., Brasil, M.V., and Barcinski, M., 2015. A maternidade no contexto do cárcere: uma revisão sistemática. Estudos e Pesquisas em Psicologia [online], 15(2), pp. 509-528. Available from: https://doi.org/10.12957/epp.2015.17656 [Accessed 10 October 2018].

Daly, K., 2006. Feminist thinking about crime and justice. In: S. Henry and M. Lanier, eds., The Essential Criminology Reader [online], pp. 205-213. Available from: https://doi.org/10.4324/9780429496592-27 [Accessed 1 July 2017].

Dell' Aglio, D.D., Santos, S., and Borges, J., 2004. Infração juvenil feminina: uma trajetória de abandonos. Interação em Psicologia [online], 8(2), pp. 191-198. Available from: http://doi.org/10.5380/psi.v8i2.3255 [Accessed 12 July 2017].

Diniz, D., 2017. Meninas fora da lei: A medida socioeducativa de internação no Distrito Federal. Brasilia: LetrasLivres.

Duarte, V.M., 2012. Discursos e percursos na delinquência juvenil feminina. Vila Nova de Famalicão: Húmus.

Duarte, V.M., and Carvalho, M.J.L. de, 2013. (Entre)Olhares sobre delinquência no feminino. Ex Aequo [online], no 28, pp. 31-44. Available from: 
https://repositorio.ismai.pt/bitstream/10400.24/196/1/3VD.pdf [Accessed 12 July 2017].

Espinoza, O., 2004. A mulher encarcerada em face do poder punitivo. São Paulo: IBCCRIM.

Ferreira, N.S. de A., 2002. As pesquisas denominadas "estado da arte". Educação e Sociedade [online], ano XXIII, $\mathrm{n}^{-}$79, agosto, pp. 257-272. Available from: https://doi.org/10.1590/S0101-73302002000300013 [Accessed 12 October 2018].

Foucault, M., 1999. História da sexualidade I: A vontade de saber. $13^{\text {th }}$ ed. Trans.: M.T. Albuquerque and J.A. Albuquerque. Rio de Janeiro: Graal.

Gallego, L.L., 2017. Tramas narrativas: Adolescentes mujeres privadas de libertad en el Sistema Penal Juvenil Uruguayo. Montevideo: Ediciones Universitarias, Universidad de la República.

Giordano, P., Cernkovich, S., and Rudolph, J., 2002. Gender, crime and desistance: toward a theory of cognitive transformation. American Journal of Sociology [online], 107(4), pp. 990-1064. Available from: https://doi.org/10.1086/343191 [Accessed 12 October 2018].

Goffman, E., 1974. Manicômios, prisões e conventos. Trans.: D.M. Leite. São Paulo: Perspectiva.

Haraway, D., 1995. Saberes localizados: a questão da ciência para o feminismo e o privilégio da perspectiva parcial. Cadernos Pagu [online], no 5, pp. 07-41. Available from: https://periodicos.sbu.unicamp.br/ojs/index.php/cadpagu/article/view/1773 [Accessed 12 October 2018].

Harding, S., 1998. ¿Existe un método feminista? In: Eli Bartra, ed., Debates en torno a una metodología feminista. Ciudad de México: UNAM, pp. 09-34.

Heidensohn, F., 1996. Women and Crime. $2^{\text {nd }} \mathrm{ed}$. London: Red Globe Press.

Instituto de Pesquisa Econômica Aplicada and Fórum Brasileiro de Segurança Pública, 2018. Atlas da violência 2018 [online]. Rio de Janeiro: IPEA, FBSP. Available from: http://www.ipea.gov.br/portal/images/stories/PDFs/relatorio institucional/180604 atlas da violencia 2018.pdf

Kruttschnitt, C., 2013. Gender and crime. Annual Review of Sociology [online], vol. 39, pp. 291-308. Available from: http://doi.org/10.1146/annurev-soc-071312-145605 [Accessed 11 December 2017].

Larrauri, E., 2008. Mujeres y sistema penal: Violencia doméstica. Buenos Aires: B de F.

Lemgruber, J., 1999. Cemitério dos vivos: Análise sociológica de uma prisão de mulheres. $2^{\text {nd }}$ ed. Rio de Janeiro: Forense.

Marcondes, M.M., et al., 2013. Dossiê mulheres negras: Retrato das condições de vida das mulheres negras no Brasil. Brasilia: IPEA.

Matos, R., 2008. Vidas raras de mulheres comuns: Percursos de vida, significações do crime e construção da identidade em jovens reclusas. Coimbra: Almedina.

Mazzocchetti, J., 2005. L'adolescente en rupture: Le placement au féminin. Louvain-laNeuve: Academia Bruylant. 
McCall, L., 2005.The complexity of intersectionality. Signs. Journal of Women in Culture and Society [online], 30(3), pp. 1771-1800. Available from: https://doi.org/10.1086/426800 [Accessed 18 October 2018].

Mendes, S. da R., 2014. Criminologia feminista: Novos paradigmas. São Paulo: Saraiva.

Méndez, E.G., 2006. Evolución histórica del derecho de la infância: ¿Porque una historia de los derechos de la infância? In: ILANUD et al., eds., Justiça, adolescente e ato infracional: Socioeducação e responsabilização. São Paulo: Ilanud, pp. 7-23.

Miller, J., 2002. The strengths and limits of 'doing gender' for understanding street crime. Theoretical Criminology [online], 6(4), pp. 433-460. Available from: https://doi.org/10.1177/136248060200600403 [Accessed 18 October 2018].

Miller, J., 2014. Doing crime as doing gender? Masculinities, femininities, and crime. In: R. Gartner and B. McCarthy, eds., The Oxford Handbook of Gender, Sex and Crime. New York: Oxford University Press, pp. 19-40.

Ministério de Justiça, 2015. Departamento Penitenciário Nacional. Levantamento Nacional de Informações Penitenciárias - Infopen Mulheres [online]. Brasilia: DEPEN. Available from: http://www.justica.gov.br/noticias/estudo-traca-perfil-da-populacaopenitenciaria-feminina-no-brasil/relatorio-infopen-mulheres.pdf [Accessed 28 July 2018].

Ministério dos Direitos Humanos, 2017. Secretaria Nacional de Promoção dos Direitos da Criança e do Adolescente. Levantamento anual do Sistema Nacional de Atendimento Socioeducativo (2014) [online]. Brasilia. Available from: https://es.scribd.com/document/364368029/Levantamento-SINASE-2014-2017

Ministério dos Direitos Humanos, 2018a. Levantamento anual do Sistema Nacional de Atendimento Socioeducativo (2015) [online]. Brasilia. Available from:

https://www.mdh.gov.br/navegue-por-temas/crianca-eadolescente/Levantamento_2015.pdf/@@download/file/Levantamento_2015.pdf

Ministério dos Direitos Humanos, 2018b. Levantamento anual do Sistema Nacional de Atendimento Socioeducativo (2016) [online]. Brasilia. Available from: https://www.mdh.gov.br/todas-asnoticias/2018/marco/Levantamento 2016Final.pdf

Morosini, M.C., 2015. Estado do conhecimento e questões de campo científico. Educação [online], 40(1), jan./abr., pp. 101-116. Available from: http://doi.org/10.5902/1984644415822 [Accessed 28 October 2018].

Pereira, T. da S., 2008. Direito da Criança e do Adolescente: Uma proposta interdisciplinar. $2^{\text {nd }}$ ed. Rio de Janeiro: Renovar.

Perrot, M., 1995. Escrever uma história das mulheres: relato de uma experiência. Cadernos Pagu [online], no 4, pp. 9-28. Available from: https://periodicos.sbu.unicamp.br/ojs/index.php/cadpagu/article/view/1733 [Accessed 28 July 2018].

Potter, H., 2013. An argument for black feminist criminology: understanding African American women's experiences with intimate partner abuse using integrated 
approach. In: M. Chesney-Lind and L. Pasko, eds., Girls, Women and Crime: Selected Readings. Los Angeles: Sage.

Quivy, R., and Campenhoudt, L.V., 2005. Manual de investigação em ciências sociais. $4^{\text {th }}$ ed. Trans.: J.M. Marques, M.A. Mendes and M. Carvalho. Lisbon: Gradiva.

Rago, M., 1998. Epistemologia feminista, gênero e história. In: J.M. Pedro and M. Grossi, eds., Masculino, feminino, plural. Florianópolis: Mulheres, pp. 21-41.

Saraiva, J.B.C., 2003. Adolescente em conflito com a Lei: Da indiferença à proteção integral: uma abordagem sobre a responsabilidade penal juvenil. Porto Alegre: Livraria do Advogado.

Sardenberg, C. M. B., 2002. Da crítica feminista à ciência a uma ciência feminista? In: A.A. Costa and C.M.B. Sardenberg, eds., Feminismo, ciência e tecnologia. Salvador: Rede Feminista Norte e Nordeste de Estudos e Pesquisa sobre Mulher e Relações de Gênero (REDOR) / Núcleo de Estudos Interdisciplinares sobre a Mulher (NEIM) / Universidade Federal da Bahia, pp. 89-120.

Secretaria de Direitos Humanos da Presidência da República, 2012. Atendimento socioeducativo ao adolescente em conflito com a lei - levantamento nacional (2011) [online]. Brasilia. Available from: https://www.mdh.gov.br/navegue-portemas/crianca-e-adolescente/SinaseLevantamento2011.pdf

Secretaria de Direitos Humanos da Presidência da República, 2014. Levantamento anual dos/as adolescentes em cumprimento de medida socioeducativa (2012) [online]. Brasilia. Available from: http://www.sed.sc.gov.br/documentos/programa-privacaoespacos-de-liberdade/levantamentos/5409-sinase-levantamento-2012

Secretaria de Direitos Humanos da Presidência da República, 2015. Levantamento anual SINASE 2013: Privação e restrição de liberdade [online]. Brasilia. Available from: https://www.mdh.gov.br/navegue-por-temas/crianca-eadolescente/Levantamento 2013 junho2015 Verso RestrioePrivaodeLiberdade.p $\underline{\mathrm{df}}$

Senador Lindbergh Farias, 2016. Relatório final: CPI assassinato de jovens [online]. Brasilia: Senado Federal. Available from: http://www12.senado.leg.br/noticias/arquivos/2016/06/08/veja-a-integra-dorelatorio-da-cpi-do-assassinato-de-jovens [Accessed 18 October 2018].

Smart, C., 1980. Women, Crime and Criminology: A Feminist Critique. London: Routledge.

Soares, B., and Ilgenfritz, I., 2002. Prisioneiras: Vida e violência atrás das grades. Rio de Janeiro: Garamond.

Sposato, K.B., 2013. Direito penal de adolescentes: Elementos para uma teoria garantista. São Paulo: Saraiva.

West, C., and Zimmerman, D.H., 1987. Doing gender. Gender and Society [online], 1(2), pp. 125-151. Available from: https://doi.org/10.1177/0891243287001002002 [Accessed 18 October 2018]. 
Dissertations (Master's) and theses (Doctorate) consulted

Almeida, N.O.G.L., 2011. Adolescente-mãe em conflito com a lei: Vivência da maternidade em cumprimento da medida socioeducativa. Dissertação, Mestrado em Família na Sociedade Contemporânea. Universidade Católica do Salvador.

Almeida, V.C.T.G., 2007. Adolescentes autoras de ato infracional: Discurso, identidade e representação. Dissertação, Mestrado em Letras, Universidade Federal do Mato Grosso do Sul.

Alvarez, M.C., 1989. A emergência do Código de Menores de 1927: Uma análise do discurso jurídico e institucional da assistência e proteção aos menores. Dissertação, Mestrado em Sociologia. Universidade de São Paulo, Faculdade de Filosofia, Letras e Ciências Humanas, Departamento de Sociologia.

Andrade, B.S.A.B. de, 2011. Entre as leis da ciência, do Estado e de Deus: O surgimento dos presídios femininos no Brasil. Dissertação, Mestrado em Antropologia Social. Universidade de São Paulo, Faculdade de Filosofia, Letras e Ciências Humanas, Departamento de Antropologia.

Aranzedo, A.C., 2012. O envolvimento de meninas e mulheres jovens em atos infracionais. Tese, Doutorado em Psicologia. Universidade Federal do Espírito Santo.

Araújo, D.B., 2004. O perfil das adolescentes que cometeram atos infracionais no ano 2000. Dissertação, Mestrado em Psicologia. Universidade Federal da Bahia.

Arruda, A.B., 2013. Medida socioeducativa de privação de liberdade em uma unidade de internação em Belém/PA. Dissertação, Mestrado em Psicologia. Universidade Federal do Pará.

Arruda, J.S. de, 2011. "Para ver as meninas": Um estudo sobre as adolescentes em cumprimento de medida socioeducativa de internação na CASE/Salvador. Dissertação, Mestrado em Estudos Interdisciplinares Sobre Mulheres, Gênero e Feminismo. Universidade Federal da Bahia.

Barbosa, M.J.L., 2016. É babado, confusão e gritaria: As histórias de travestis recifenses sob um olhar da criminologia crítica. Dissertação, Mestrado em Ciências Jurídicas. Universidade Federal da Paraíba.

Bassi, S., 2011. Sexualidade feminina em privação de liberdade: Construindo relações sociais mais autênticas. Dissertação, Mestrado em Serviço Social. Pontifícia Universidade Católica de São Paulo.

Bretan, M.E.A.N., 2008. Os múltiplos olhares sobre o adolescente e o ato infracional. Dissertação, Mestrado em Direito. Universidade de São Paulo.

Coêlho, J.P.L., 2013. Estudos sobre a dinâmica de organização de "si mesmo" de adolescentes do sexo feminino em conflito com a lei. Dissertação, Mestrado em Psicologia. Universidade Federal do Ceará.

Costa, D.L.P.C. de O., 2015. As adolescentes e a medida socioeducativa de internação: Rompendo o silêncio. Dissertação, Mestrado em Processos de Desenvolvimento Humano e Saúde. Universidade de Brasilia. 
Diamantino, D.T., 2015. Do lar para o mundão: Sentidos subjetivos do ato infracional construídos pelas adolescentes em privação de liberdade. Dissertação, Mestrado em Psicologia. Universidade Federal da Bahia

Duarte, J. das F., 2016. Para além dos muros: As experiências sociais das adolescentes privadas de liberdade. Dissertação, Mestrado em serviço Social. Pontifícia Universidade Católica do Rio Grande do Sul.

Fachinetto, R.F., 2008. A "Casa de Bonecas": Um estudo de caso sobre a unidade de atendimento sócio-educativo feminino do RS. Dissertação, Mestrado em Sociologia. Universidade Federal do Rio Grande do Sul.

Flauzina, A.L.P., 2006, Corpo negro caído no chão: O sistema penal e o projeto genocida do estado brasileiro. Dissertação, Mestrado em Direito. Universidade de Brasilia, Faculdade de Direito, Coordenação de Pós-Graduação em Direito, Curso de Mestrado em Direito.

Gomes, D.D. de O., 2016. Da privação de direitos à privação de liberdade: Tecendo trajetórias de adolescentes negras em cumprimento de medida socioeducativa de internação. Dissertação, Mestre em Serviço Social, Trabalho e Questão Social. Universidade Estadual do Ceará.

Hulle, L. de O., 2006. Meninas em conflito com a lei e com a esperança: Estrelas sem guia. Dissertação, Mestrado em Psicologia. Universidade Federal do Espírito Santo.

Jesus, R.M. de, 2011. Sonhos e desejos enquanto projetos de vida das adolescentes em conflito com a lei. Dissertação, Mestrado Profissional em Adolescente em Conflito com a Lei. Universidade Bandeirante.

Leite, O.R.L., 2013. Avaliação do atendimento socioeducativo prestado às adolescentes do Centro Educacional Aldaci Barbosa Mota. Dissertação, Mestrado em Avaliação de Políticas Públicas. Universidade Federal do Ceará.

Macedo, A.E. de A., 2014. Centro socioeducativo feminino (CESEF/PARÁ): Alguns aspectos genealógicos. Dissertação, Mestrado em Psicologia. Universidade Federal do Pará.

Machado, É.B.L. do A., 2014. Medida socioeducativa de internação: do discurso (eufemista) à prática judicial (perversa) e à execução (mortificadora): Um estudo do continuum punitivo sobre adolescentes do sexo feminino em conflito com a lei na cidade do Recife, PE. Tese, Doutorado em Direito. Universidade Federal de Pernambuco.

Mendes, A.P.S.M., 2012. Narrativas de vida: Reflexões sobre juventude, violência e gênero a partir de histórias de jovens inseridas no programa PEMSE-Ponta Grossa-PR. Dissertação, Mestrado em Ciências Sociais Aplicadas. Universidade Estadual de Ponta Grossa.

Misse, M., 1999. Malandros, marginais e vagabundos e a acumulação social da violência no Rio de Janeiro. Tese, Doutorado em Sociologia. Instituto Universitário de Pesquisas do Rio de Janeiro.

Ramos, M.B., 2007. Meninas privadas de liberdade: A construção social da vulnerabilidade penal de gênero. Dissertação, Mestrado em Serviço Social. Universidade Católica do Rio Grande do Sul. 
Rocha, L.C., 2016. "As cumades das facções": As relações de gênero e sexualidade, dentro das facções Okaida e Estados Unidos em João Pessoa. Dissertação, Mestrado em Ciências Jurídicas. Universidade Federal da Paraíba.

Rocha, W.L., 2013. Música em espaço de privação de liberdade: A música afro-brasileira em unidade feminina de atendimento ao adolescente em conflito com a lei. Dissertação, Mestrado em Música. Universidade Federal do Rio de Janeiro.

Rodrigues, A.S., 2017. Racismo no "brete": Onde elas (não) estão? Estudo qualitativo sobre jovens negras, egressas do sistema socioeducativo brasileiro. Tese, Doutorado em Serviço Social. Pontifícia Universidade Católica do Rio de Janeiro.

Santos, J.H. dos, 2011. Entre desvios e normas: Infração juvenil feminina na cidade de Natal$R N$. Dissertação, Mestrado em Ciências Sociais. Universidade Federal do Rio Grande do Norte.

Santos, P. dos, 2008. "Fazendo a cabeça": Processos de (trans)formação de jovens em cumprimento de medida socioeducativa de internação. Dissertação, Mestrado em Educação. Universidade Federal do Espírito Santo.

Silva, G.K.C., 2017. Política pública de educação para adolescentes infratores do estado do Pará e a realização do projeto de vida. Dissertação, Mestrado Direito, Políticas Públicas e Desenvolvimento Regional. Centro Universitário do Estado do Pará.

Silva, M. da P. Da, 2016. A maternidade na medida socioeducativa de privação de liberdade: Práticas, sentidos e afetos. Dissertação, Mestrado Profissional em Adolescente em Conflito com a Lei. Universidade Bandeirante.

Silva, M.M.C., 2008. Meninas à prova: Um estudo sobre as justificações dadas por adolescentes em conflito com a lei. Dissertação, Mestrado em Sociologia e Direito. Universidade Federal Fluminense.

Silva, M.M.C., 2013. Nos mundos do Departamento Geral de Ações Socioeducativas: Adolescentes, agentes e técnicos nos contextos da administração da justiça para a juventude. Tese, Doutorado em Sociologia. Universidade do Estado do Rio de Janeiro.

Silva, T.L., 2014. Feminilidade, parceria amorosa e a entrada das adolescentes no tráfico de drogas: Uma contribuição da psicanálise. Dissertação (Mestrado em Psicologia), Universidade Federal de Minas Gerais.

Silveira, I.L., 2013. Uma jovem mulher, sua parceria amorosa e o tráfico de drogas. Dissertação, Mestrado em Psicologia. Pontifícia Universidade Católica de Minas Gerais.

Sousa, M.F. de, 2012. Representações sociais de adolescentes: ato infracional e projeto de vida. Dissertação, Mestrado em Educação. Universidade Federal do Pará.

Souza, E.P., 2014. A formação de par-amoroso entre as adolescentes em cumprimento de medida socioeducativa de internação. Dissertação, Mestrado em Psicologia. Universidade Federal de Minas Gerais. 
Vilarins, N.P.G., 2016. Meninas de Santa Maria: A precarização da vida na medida socioeducativa de internação. Tese, Doutorado em Política Social. Universidade de Brasilia.

Legal sources

Constituição da República Federativa do Brasil de 1988. Available from: http://www.planalto.gov.br/ccivil 03/constituicao/constituicaocompilado.htm [Accessed 28 October 2018].

Decreto $\mathrm{n}^{\mathbf{0}}$ 16.272, de 20 de dezembro de 1923. Available from: http://www2.camara.leg.br/legin/fed/decret/1920-1929/decreto-16272-20dezembro-1923-517646-publicacaooriginal-1-pe.html [Accessed 28 October 2018].

Decreto no 17.943-A, de 12 de outubro de 1927, Código de Mello Mattos. Available from: http://www.planalto.gov.br/ccivil 03/decreto/19101929/D17943Aimpressao.htm [Accessed 28 October 2018].

Decreto $n^{0}$ 99.710, de 21 de novembro de 1990. Available from: http://www.planalto.gov.br/ccivil 03/decreto/1990-1994/d99710.htm [Accessed 05 January 2019].

Decreto-lei no 2.848, de 7 de dezembro de 1940, Código Penal. Available from: http://www.planalto.gov.br/ccivil 03/decreto-lei/Del2848compilado.htm [Accessed 28 October 2018].

Lei $\mathrm{n}^{\mathrm{o}}$ 10.639, de 9 de janeiro de 2003. Available from:

http://etnicoracial.mec.gov.br/images/pdf/lei_10639 09012003.pdf [Accessed 05 January 2019].

Lei $\mathrm{n}^{\mathrm{o}}$ 12.594, de 18 de janeiro de 2012, Sistema Nacional de Atendimento Socioeducativo - SINASE. Available from:

http://www.planalto.gov.br/ccivil 03/_ato2011-2014/2012/lei/112594.htm [Accessed 28 October 2018].

Lei no 6.697, de 10 de outubro de 1979, Código de Menores. Available from: http://www.planalto.gov.br/ccivil 03/leis/1970-1979/16697.htm [Accessed 28 October 2018].

Lei no 8.069, de 13 de julho de 1990, Estatuto da Criança e do Adolescente - ECA. Available from: http://www.planalto.gov.br/ccivil 03/leis/18069.htm [Accessed 28 October 2018]. 